\title{
Conflict Management through African Indigenous Institutions: A Study of the Anyuaa Community
}

\author{
Tasew Tafese ${ }^{1, *}$ \\ ${ }^{1}$ Institute for Peace and Security Studies, Addis Ababa, Ethiopia \\ *Correspondence: Institute for Peace and Security Studies, Addis Ababa, Ethiopia. E-mail: tasew21@gmail.com
}

Received: January 19, 2016

Accepted: January 31, 2016

Online Published: January 31, 2016

doi:10.5430/wjss.v3n1p22

URL: http://dx.doi.org/10.5430/wjss.v3n1p22

\begin{abstract}
Traditional African societies are closely attached with deep-rooted cultural facts and elders play a major roles to solve problems, create strategies and shape local visions based on skills and wisdoms. To do this, they use their past experience and knowledge which transmit from generation to generation. That accumulated knowledge of elders are indigenous knowledge which cultivated from the local community. Therefore, elders apply their indigenous knowledge for development planning as well as solving social problems. To obtain the purpose of this paper, the author selected the Anyuaa society from East Africa who are living in Ethiopia and South Sudan along the border via Gambella. They have traditional institutions known as Nyieye and Kwaaro to implement indigenous knowledge in order to handling social problems including conflicts. Thus, in the body the paper, the concepts of indigenous knowledge, conflict resolution, roles of indigenous knowledge in conflict resolution, Anyuaa's traditional institutions such as the Noblship (Nyieya) and the headman (Kwaaro) including their conflict resolution process, compensation and purification are briefly discussed. The discussion supported by pictures that help us easily to understand the relevant linkage of indigenous knowledge to conflict resolution. Finally, conclusion is forwarded to accentuate how the African traditional institutions play their role to manage conflicts through their indigenous knowledge.
\end{abstract}

Keywords: indigenous-knowledge, conflict-resolution, Anyuaa's traditional institutions, skills and wisdoms

\section{Introduction}

Conflict is a natural phenomena in the life of human beings which occur in relation of interaction for socio-cultural, economic and political purposes. The universe itself revolve through conflict. Thus, conflict is impossible to avoid from the life of human beings rather treat in a positive way for functional outcomes, as Džuverović (2011:53) pinpoints "conflict is an integral part of our lives." According to Osaghae (2000), conflict could occur between people of different communities normally over the determination of rights ownership of natural resources and raid of live-stock. As a result, states provide western model of conflict resolutions to minimize the destructive features of conflict in the communities. Traditional societies also develop conflict management mechanisms through their cultural perceptions. Accordingly, many African societies have traditional institutions to apply indigenous knowledge and laws to settle all types and levels of conflict.

In African traditional societies, conflict management through indigenous institutions perform a healing function. It provides opportunity for examinations of alternative positive decision to resolve differences. As a result, the role actors are elders, clan chiefs, prominent leaders, acceptable and respected persons (eg., great hunters) and also they use council of elders, king's court, peoples assemblies, etc for dispute settlement and justice dispensation (Nwosile, 2005). This is because elders could have wisdom and knowledge; and respect as trustworthy mediators. So that, traditional institutions play a proactive role to promote social cohesion, peace, harmony, co-existence; and a reactive role in resolving disputes which have already occurred (Department of Justice and Constitutional Development, 2008). Similarly, according to Fred-Mensah (2005:1), traditional conflict resolution mechanism is a social capital, defined as the "capability of social norms and customs to hold members of a group together by effectively setting and facilitating the terms of their relationship...sustainability facilitates collective action for achieving mutually beneficial ends."

Therefore, traditional conflict resolution processes in Africa are part of a well-structured, time-proven social system 
geared towards reconciliation, maintenance and improvement of social relationships. For instance, the Akans traditional court in Ghana (Okrah, 2003); the Tswana culture in Botswana (Ngcongco, 1989); the endogenous gacaca courts in Rwanda (Mutisi, 2009); the Acholi Justice System in Northern Uganda (Wasonga, 2009); the Kpelle people of Liberia and the Ndendeuli of Tanzania (Bob-Manuel, 2000); the Yoruba peoples indigenous law (Olaoba, 2001); the Igbo traditional institutions (Bennett, 1993, \& Olaoba, 2001); and the Pondo tribe of Zulu in South Africa justice system (Olaoba, 2001, Ajayi and Buhari, 2014) are some of structured African traditional institutions that play major roles in conflict resolution.

In this way, African societies emphasized to social harmony as the overriding ideology of social control. This has been well-demonstrated in the conception and application of the philosophies of ubuntu among the indigenous communities of Southern Africa (Masina, 2000); and kanye ndu bowi among the Buem of the Ghana-Togo border area (Fred-Mensah, 2000). Moreover, the essence of conflict management in traditional African communities, states and regions include to remove the root-causes of the conflict; reconcile the conflicting parties genuinely; to preserve and ensure harmony to set the right setting for societal production and development. Therefore, conflict management using indigenous institutions in various African communities, states, and regions including contemporary African regional institutions have a chance to embrace this paradigm through the institutionalization of the panel of the wise.

\section{Indigenous Knowledge (IK)}

The question "What is Indigenous knowledge?" is usually asked by scholars seeking to understand a cognitive system. Finding a satisfactory answer to this question by identifying the concepts of indigenous knowledge is the necessary first step to illustrate the relation of indigenous knowledge to conflict resolution. In this case, IK reflects in different ways in different societies. Scholars also use different terms to reflect the concept of IK in literatures. For instance, DeWalt (1994) notes the term "local knowledge" might be more accurate; also see Brush (1993) for elaboration. In this understanding, IK is stored in culture in various forms, such as traditions, customs, folk stories, folk songs, folk dramas, legends, proverbs, myths, etc, and transfer it from generation to generation orally. Thus, traditional African societies give different names based on their traditional life and purpose. According to Akabogu (2002), IK has different but closely related names such as 'folk knowledge', 'local knowledge or wisdom', 'non-formal knowledge', 'culture', 'indigenous technical knowledge', 'traditional ecological knowledge', 'traditional knowledge', and others. All these terms have similar concepts and refer to how members of a community perceive and understand their environment and resources, particularly the way they convert those resources through labor.

On the other hand, IK is also a unique cultural knowledge in traditional society. For instance, according to Warren (1991), since every population is unique in terms of its environment, its resources, and its tools (both physical and conceptual), IK will also be unique. Similarly, according to Kwaku and Morena (2010), IK is a unique local knowledge to a given culture or society. In this understanding, IK exists in rural and urban societies as part of life that their livelihood depends on specific skills and knowledge for survival. Therefore, IK is an intercultural and interdisciplinary sources of unique local knowledge to a given culture that embraces the contexts of specific environment.

Accordingly, IK refers to a large body of knowledge and skills which developed outside the formal system including development planning, environmental assessment, resource management, local conservation of biological resources, and conflict resolution (World Bank, 1998). For instance, according to Boven and Morohashi (2002), it is relevance to development process such as agriculture, animal husbandry, traditional medicine, saving and lending, community development, poverty alleviation, and peaceful coexistence. In this case, IK is a knowledge that apply to find a solution for daily life as well as development concept of traditional society. Likewise, their traditional knowledge is useful to resolve conflicts within a society as conflict is a natural phenomena of human life. Therefore, traditional societies apply their local knowledge to sustainable development as well as peaceful co-existence by resolving conflicts which occur in a specific community.

\section{Conflict Resolution}

Conflict resolution is a process of peace making and a means of handling conflicts in a society to create peace when conflicts occur either in a family, groups or interpersonal relations. According to Michael (2006), conflict resolution occurs by listening to and providing opportunities to meet the needs of all parties, and to adequately address interests; so that each party is satisfied with the outcome. Consequently, conflict resolution is usually involves consensus, "horse trading", conciliation and other techniques (Kestner and Ray, 2002). For that reason, the processes of conflict 
resolution is vary from society to society such as negotiation, mediation and arbitration.

In this understanding, negotiation is the act of dealing with or bargaining with others, through mutual decision, in order to arrange the terms of a transaction or agreement, as in the preparation a contract or treaty (Babbitt, 2006). It occurs between two parties talking to one another; there can be one negotiator serving as a go-between between two parties or there can be two or more negotiators representing the disputing parties (Hampson, 2006; Babbitt, 2009b). In this case, negotiation involves the two direct conflicting parties in a process of decision which seeks to bring them into voluntary agreement. Although negotiation is not about who is right or wrong in a situation or conflict, it is the process of resolving a situation through agreement. Thus, its purpose is to arrange for or bring about settlements by means of discussion.

On the other hand, "mediation is an informal process in which disputing parties discuss their situation with the goal of reaching a mutual satisfactory agreement or gaining new perceptions about the situation, with the help of a neutral third party who serves as an intermediary to assist the disputing parties to reach their own agreement or resolution" (Kestner and Ray, 2002:208). As a result, mediation is a voluntary or confidential process in which a neutral third party facilitator helps people to discuss a difficult issue and negotiate an agreement. Thus, mediation is using third party to help the conflicting parties to come to neutrally satisfactory agreement. Accordingly, Schellenberg (1996) states that the third neutral party follow mediation process including gathering information, framing the issues, developing options, negotiating, and formalizing agreements. However, the mediator doesn't have any decision making power rather parties create their own solutions. Therefore, the mediator's task is not to solve the problem for the disputants but to help them to find a way to solve the problem themselves.

\section{Roles of Indigenous Knowledge in Conflict Resolution}

Traditional conflict managements are playing an important role in resolving conflicts and maintaining peace and stability in a community. To resolve conflicts and maintain peace in a specific community, indigenous knowledge plays major role. According to Macfarlane (2007), IK is run by elders who are well known and respected members of the community and may comprise religious leaders, wise-men and other community leaders. Similarly, according to Fiseha, et al., (2011), prominent and old-age groups within a society are the source of indigenous knowledge as they have experience and critical perception about their environment. Such old-age's perception are different from society to society. For instance, Regassa, et al., (2008) pinpoint that traditional practices are deeply rooted in different ethnic groups and arise from old-age practices that have regulated the relationships of the peoples in a community. Accordingly, elders are associated with the cultural norms and beliefs of the peoples, and gain their legitimacy from the community values instead of state. In other words, the traditional dispute resolution mechanisms function on the basis of local customary practices or cultural norms based on indigenous knowledge.

Consequently, a true and lasting peace requires a culture for peace that is a comprehensive, society wide system of values, beliefs, and attitudes. Therefore, according to Bar-Siman-Tov (2004), in traditional and relatively undifferentiated society's chiefs, elders, or other leading figures play mediating or judicial roles in bringing injured parties and their kin into normal civility. In this case, there are local actors and traditional community based decision making method to manage and transform conflict within a community. Thus, local mediation typically incorporates consensus building based on open discussions to exchange information and clarify issues. Accordingly, conflicting parties are more likely to accept guidance from these mediators than from other sources because an elder's decision does not entail any loss of face and is backed by social pressure. In this understanding, traditional institutions, elders, chiefs and other prominent leaders play critical roles to invest indigenous knowledge to conflict resolution and maintain stability within a community. Therefore, traditional institutions are generated by the society within a particular community according to the perceptions of their culture and different groups of people involve within resolution process as audience besides of conflict parties and mediators.

\section{Anyuaa's Traditional Institutions}

The Anyuaa community is living along the border of Ethiopia and the Republic of South Sudan; specifically in Gambella and Puchalla respectively. They have been established traditional institutions to administer the specific societies based on their indigenous knowledge which classified into three: First, the Nobleship institution which administered by Nyieye (plural), or Nyieya (singular). The headquarters of the king is in Pochalla county of Jonglei State in southeastern part of South Sudan, at the specific place of Adongo. Second, the headmanship institution which owned by Kwaari (plural) or Kwaaro (singular). Third, the spiritual leader and serve as permanent 
representative of the nobleship institution possessed by Nyibur. Family Councils are also the core micro institution to control the peaceful interactions of the grassroots society under the supervision of the concerned village administrator (Tasew, 2010).

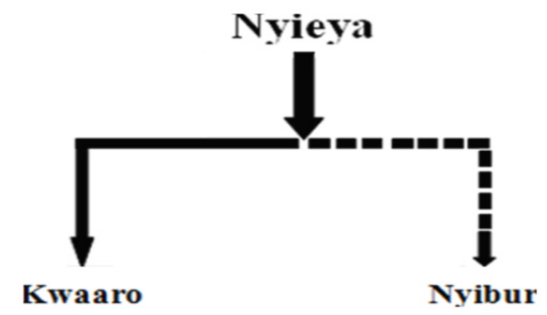

Figure 1. Major Anyuaa's Traditional Institutions

Nyieya is hierarchically the top position of Kwaaro and Nyibur, however, they are relatively independent in their village. The two major institutions (Nyieya and Kwaaro) administration is not restricted according to their power. Accordingly, if a village is administered by Nyieya, Kwaaro is not eligible to intervene in that administrative system regarding to the people, but land is the property of it. Similarly, if a village is administered by Kwaaro, Nyieya can live as respected guest and concerned about the people, but cannot make any administrative intervention in that village. If a village is administered by neither Nyieya nor Kwaaro; Nyieya selects one person from the particular village as permanent representative of Nyieya, i.e. Nyibur.

\subsection{The Nobleship Institution (Nyieya)}

The royal family, the great Anyuaa king, is categorized as one of the Anyuaa's traditional institution. The Anyuaa noble, Nyieya is powerful and has an absolute power. Nyieya has no land. However, all Anyuaa people are belong to Nyieya. It has an ultimate power and his word is respected in all over the Anyuaa people. Accordingly, nobility depends up on birth and a ceremony of investiture to wear the royal emblem, Ucuok on his neck. Thus, the noble structure belongs into two lineages such as Tung-Goch and Tung-Nyiudola. Historically, the two lineage groups compete each other to obtain the royal emblem, Ucuok. At early stage it was in the hands of Tung-Goch, however, later it transferred into Tung-Nyiudola. Therefore, no Anyuaa has right to be a Nyieya unless he is born into Tung-Nyiudola lineage. Similarly, a man cannot become a Nyieya by act of birth alone but by investiture with the emblems of nobility. If he is not invested with them he never becomes a noble and his descendants are forever excluded from investiture and Nyieya lineage as it is a lineage heritage of royal family. The following pictures also reveal the process of investiture in April, 2012.

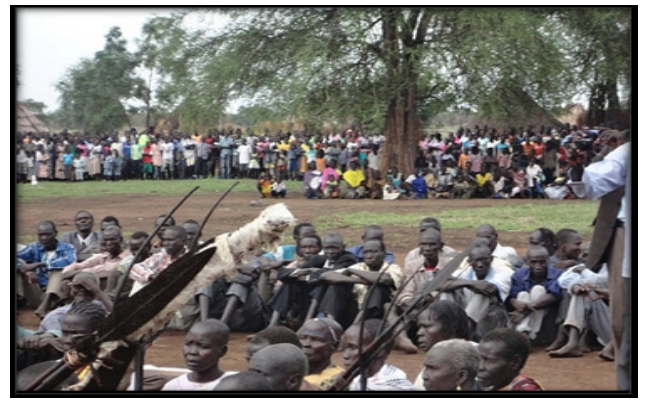

Picture 1. Inaugural Ceremony

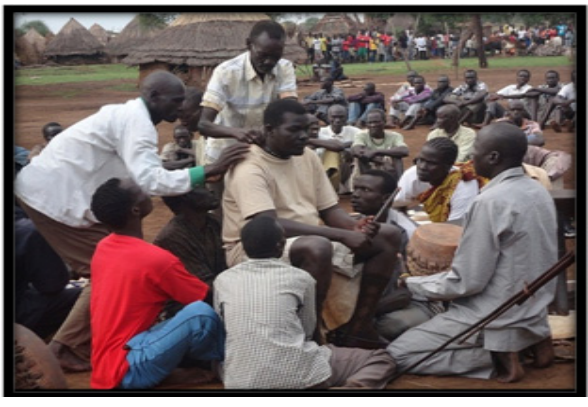

Picture 2. Elders Put the Royal Emblem, Ucuok, on the King's Neck 


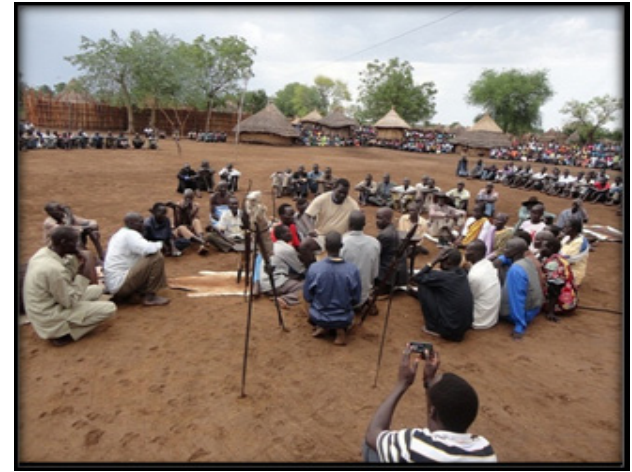

Picture 3. The King Discuss with Elders after Investiture

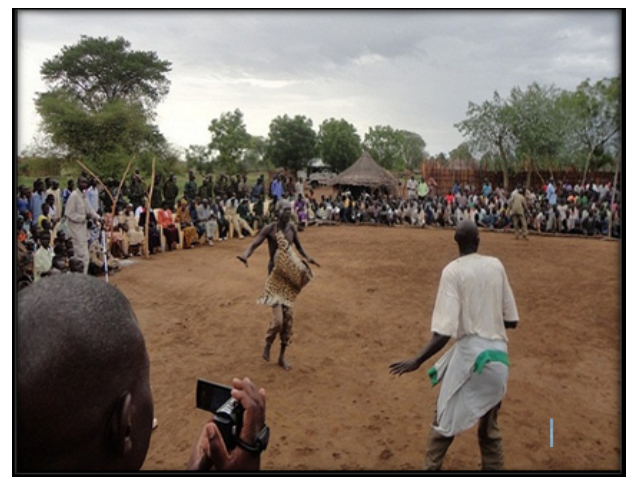

Picture 4. Nyibur Beats Udola Drum at Inaugural Ceremony

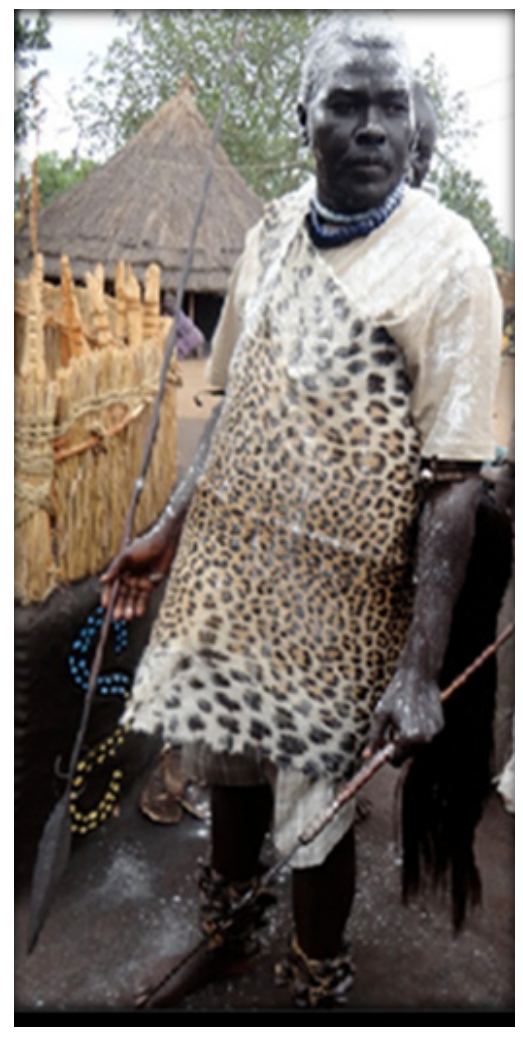

Picture 5. King Akwai Agada Akwai Cham at His Inauguration

Source: Photos taken by the author (April, 2012) and also available at www.anyuakmedia.com

In the Nyieya institution, there are different officials and structurally worked to facilitate Nyieya's institutional justice during the time of conflict, dispute and other social phenomenon. Some of the major officials and responsibilities are described below.

Nyikugu: Head of Cuud and serves as the main supervisor as an immediate boss of others with the side of Nyieya. Sometimes he is considered as representative of Nyieya at the court place, Cuud. If there is appeal of accusation from the society, the adjudication case take by Nyikugu.

Nyieatowieli: he is serving as public relationship of the Jayie (the 'Cabinet'). He takes message from the king of his village to another village king or headman to consolidate their external relationship. He acts like diplomat. He is also serving to address message to the particular village community from the king. He also serves to report the result of discussion during adjudication at the Cuud for Nyikugu or Nyieya. 
Kuey Luak: an armed force of a strong age group from Joluak - an age group who has potential to be soldier - who keep the Nyieya structure including the assembly and court place, Cuud.

Nyibur: an authorized representative of Nyieya or Kwaaro for specific village if there is neither Nyieya nor Kwaaro and accountable for Nyieya. Besides, he served as spiritual leader to bless the people, land, water, cattle and pray every time for Naam-Jwok, river god. When Nyieya possesses the emblems during the time of investiture, he beats the Udola drum (see picture 4 above), which brought by the 'river man' (Ucuudho/Ukiro) with Ucuok bead.

Nyieya has an assembly place, which is serving as court station known as Cuud. Every court system takes place in this court station. When an age group who served as Kuey Luak becomes old age they leave their armed force for the next strong age group and gathered to the place of Cuud. After they got the place of Cuud their name is known as Jocuud. Jocuud served as privy council and teach different age groups at any time and any place including hearth at the time of wic mäc - a head fire during night - to keep social morality.

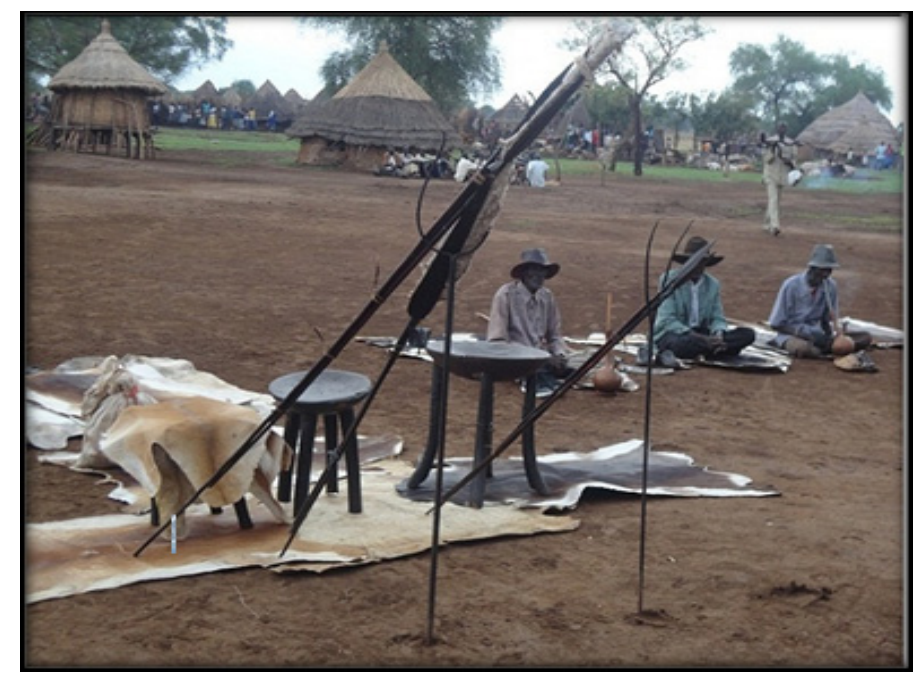

Picture 6. Jocuud, Who Serve as Privy Council of Nyieya

Therefore, all the Nyieya officials, including Jocuud are commonly known as Jayie. The composition of officials are from Nyieya lineage and others to serve Nyieya's structure for long live of their king.

\subsection{The Headman Institution (Kwaaro)}

Kwaaro is landowner and distributed land to landless people in the village through Nyibur. Kwaaro carries out the administrative functions with the assistance of his officers. The following are some of senior officials appointed in cabinet of kwaaro to fulfill public duties.

Karwang- special administrator and advisor to headman/kwaaro to assist him in administrative matters and public issues. In the absence of Kwaaro he would run all affairs of the village as speaker of kwaaro.

Nyikugu-head of Burra and facilitate arbitration process during dispute resolution and also assist the administrative affairs of the village during the absence of both Kwaaro and Karwang.

Nyitoga- general council of internal affairs of the village who provided assistance to kwaaro in social, economic and cultural matters. He advocates and mobilizes the entire village for prosperity and perform as chief of security and advisor.

Nyibur- head of land tenure, and spiritual leader. He has right to distribute farmlands to residential and keeps update on the statistics of land and population. He supervises village's border demarcation and also responsibility to pray and warn the people during the time of drought, famine, harvest and epidemic disease.

Nyieatowieli- head of public relations and information serving as special messenger of Kwaaro.

Kuey luak -an armed force around Burra who provided assistance to Nyikugu in time of dispute resolution and war. It serves to keep the maintenance of Kwaaro structure and Jayie. 
Kwaaro has an assembly place, which is serving as court station known as Burra. It is a place of dispute resolution and other social services care of. When an age group, who served as Kuey luak became old, they disarmed and leave the place for young age group. After disarmed, they got the place of Burra with new name, Joburra.

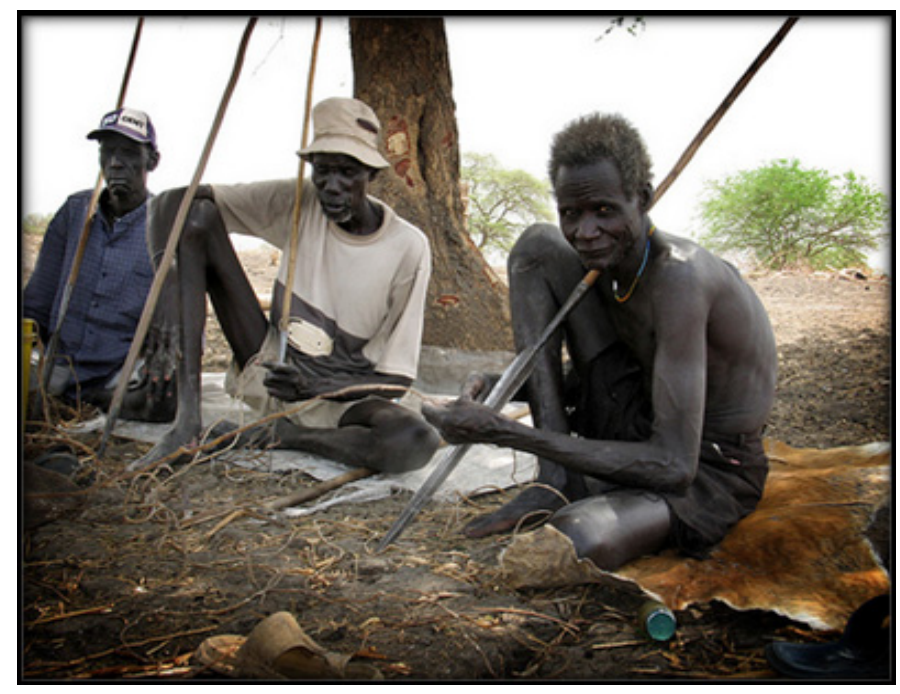

Picture 7. Joburra, Who Serve as Privy Council Of Kwaaro

The responsibility of Joburra is privy council and teach the different young age groups at any time and any place including wic mäc, and during the time of conflict or other social phenomenon.

\subsection{Anyuaa's Conflict Resolution Process}

Indigenous knowledge play major role in conflict resolution process for different traditional societies in Africa. Accordingly, Eshetu and Getu (2009) describe that indigenous conflict resolution process is qualitatively different from judicial process. It is a process where conflicts are managed with the assistance of a neutral third party and the neutral third party is depend generally on parties own choice. According to Regassa, et al., (2008), the traditional dispute resolution processes are set in motion by the offender him/herself, by his/her family or close relatives; and in some minor crimes by the victim or his/her family. Then, when a crime is committed, the perpetrator, the victim, their respective families, or any third party observers run to and ask elders to help the settlement of the conflict.

In line with scholars position regarding to traditional conflict resolution, the Anyuaa's traditional institutions engaged with different conflicts like inter-village, intra-village and homicide.

\subsubsection{Inter-village Conflict}

It is a conflict between two villages or Kwaaro and possible to mediate by neutral third party village headman (Kwaaro). However, as a conflict occur between two Kwaaro, the third neutral party (Kwaaro) is unable to mediate them, thus Nyieya interfere to resolve the conflict. During the process of resolution, the third neutral party, Kwaaro, also concerned on the issue by the side of Nyieya. In this case, Kwaaro send its Nyieatowieli to Nyieya to arbitrate them. When the Nyieya heard the conflict between the two Kwaaro, he order its Nyieatowieli to call the disputant parties to come to the Cuud and start the arbitration process to make final decision. To resolve the conflict, Nyikugu facilitate the Cuud court station for an open discussion. In time of discussion, Nyieya get advice from Jocuud and Nyikugu manage everything. Under the discussion they investigate the cause of conflict and identify the aggressor. After this identification the result is reported to Nyieya through Nyieatowieli. Finally, Nyieya reconcile and advice all of them how they live together in peace, and then order both of them to pay compensation because of their mistake for Jocuud.

\subsubsection{Intra-village Conflict}

In intra-village, conflicts occur either in intra-family and inter-family. The resolution process also take place by the family council and headman (Kwaaro). For instance, the conflict which occur within a family is mediated by family council. A family council combined up to five family elders. All of them belong to the same kinship. All family elders with their family members come to hold meeting at family council to discuss about the problem. The disputant 
parties also attend the meeting and family elders are serving as third party as arbitrator. The family elders have power to pass any decision on the disputant party if they do not agree.

On the other hand, conflict occurs between different families in the same village and the resolution procedure initiate by the third neutral family. The party calls both families to mediate them under the tree which considered as reconcile place of inter-family conflict. However, sometimes the problem is beyond the capacity of the third family. Therefore, the issue is transfer to the headman of the village to arbitration. Thus, Kwaaro give order for Nyieatowieli to call the whole community including the quarrelsome family to the place of Burra for discussion.

After the community placed at Burra, Kwaaro and Joburra take their position to listen the discussion. Then, first Nyikugu introduces the main objective of the session for the audience and then ask the victim family to explain about the cause of conflict and their discontent. They explain everything including their discontent and the audience listen their explanation. Secondly, Nyikugu asks the offender family about the main cause of the conflict to cross-check and find out the cause of conflict. If there is a gap of information between the offender and victim's explanation, Nyikugu open the floor for debate based on Anyuaa norms. The debate is only between the two conflictive parties and the audience is quietly listen them. After they reach on consensus, the issue back to the audience. The community take the issue as their concern and discuss on it deeply by mentioning their back knowledge and eye witness about the offender's and victim's family.

In all the discussion the offender's family is not allowed to give any opinion for the community in order to avoid unnecessary annoyance. On the other hand, the victim's family has right to participate on the discussion to reach an agreement with the community about the compensation. After they reach on consensus, Nyikugu tell to the offender's family about their agreement. Consequently, Nyikugu informs Nyieatowieli to report all the majorities' agreement for Kwaaro. Finally, Kwaaro listen Nyieatowieli's report and talk with Jobura to get advice and then passes judgment based on the majorities' agreement.

\subsubsection{Homicide}

Homicide is a serious offence and anti-social act. Thus, murder is a cause of serious conflict, however, it takes place in the society in different place at different time. When a person commits a murder crime, the culture obliged him/her to surrender himself for either Nyieya/Kwaaro, according to the village administrator. Therefore, once the offender reports to Cuud/Burra; Nyieya/Kwaaro fulfill everything for him/her. Nobody going to hurt him/her because he/she is under the king or headman control; even the dying family is not allowed to hurt him/her. Until the problem resolve, Nyieya/Kwaaro treat the criminal person in an affable manner, provide food and drink including tobacco as well as shelter; because a murderer is totally outcast and not allowed to mingle with others until traditional purification perform.

After once the murderer surrender to Nyieya/Kwaaro, Nyieatowieli send to gather information about the incident. Then, Nyieya/Kwaaro send message to the offender's and victim's family include other community to hold meeting around Cuud/Burra to find solution based on the gathered information. To do this, eloquent and mentally sharp elders, who respected by the society, assigned to represent the community as elder's council at Cuud or Burra. The plaintiff and defendant party have enough time to argue their case. The elders' council cross-check the circumstances and attest the crime if it is intentional or unintentional. So, the circumstantial evidences are examine thoroughly. Because of this the investigation takes a week to cross-check the case of the crime. Finally, after their long discussion, they make decision on the criminal person to pay compensation for the victim's family and perform traditional purification.

\subsection{Compensation and Purification}

Compensation is a cultural obligation to secure peace and security in the disputant parties. It is also a state of assurance of peacemaking process after their conflict resolution. As a result, compensation is replaced the in-kind payment and revenge of Anyuaa's justice. Hence, compensation is necessary for all kinds of crime except homicide during inter-village, age group, agem (a ritual bloodless revolution) and agaanya dance fighting (a full social significance of the headman dance which does in group). However, the type of compensation is depends upon the type of crime. Therefore, two types of compensation process has been developed by their traditional institutions. They are in terms of cultural objects and human beings according to the interest of the injured party.

\subsubsection{Cultural Objects}

A person who commit a crime is oblige to pay compensation for the dying family in terms of valuable cultural materials. All dowry during marriage are also serving as compensation. Especially, the main expensive cultural 
materials are Dimui, Skin of Tiger, Athero, Dem, Ogudi, Garrie, Thinjet, Elephant teeth, Gun, Cows or Bulls, etc. (see some of them in the following pictures)

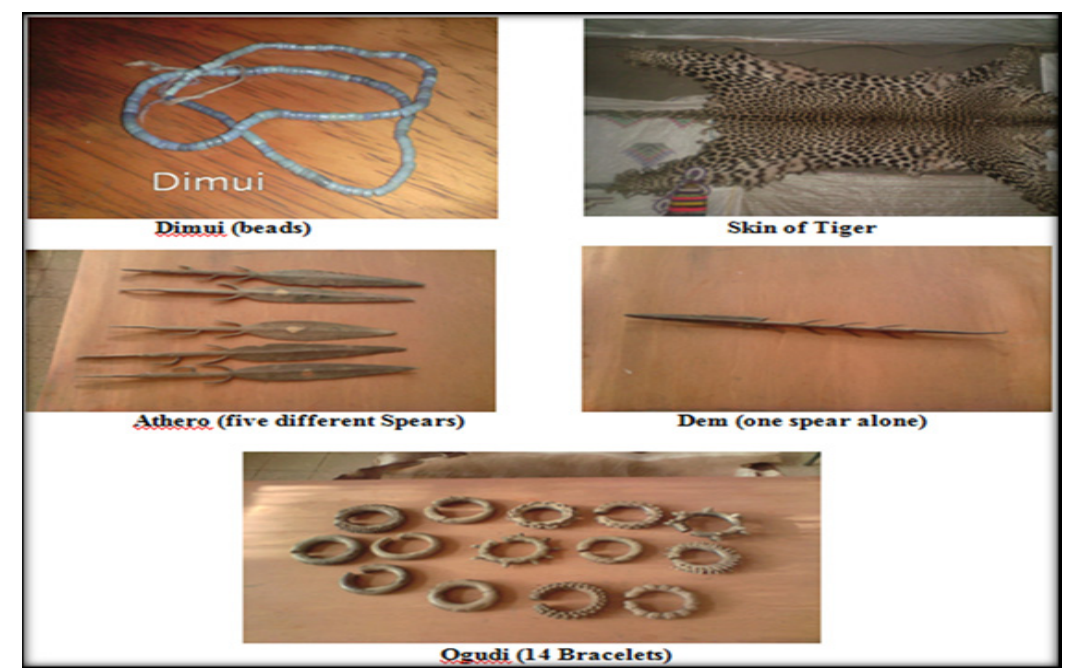

Picture 8. Valuable Cultural Materials Which are Paying for Compensation

\subsubsection{Human Beings}

In case of homicide, the victim's family needs substitution of human being instead of cultural compensation. The victim's family selects a female or a male from the offender family children according to their interest and takes her/him to their family, and then they give care as their child. In this case, most of the time they take female to become a wife of the dying brother, cousin or uncle. Her child is treated and accepted as the offspring of the dying person.

Accordingly, in both compensation processes, a person who commits crime may be poor and unable to pay. In this case, the compensation is paid for the victim's family into one of the following three ways.

1. A poor person surrenders himself for Nyieya/Kwaaro and then Nyieya/Kwaaro pay the compensation for the victim's family. Instead, a poor person remains as servant of Nyieya/Kwaaro.

2. A rich man who recognized by the elder's council has right to pay compensation for a poor person. Instead, a poor person who commits crime has also adopt as a child of the rich man.

3. If a poor person fails to get a rich man who is willing to adopt him as a child, then he/she becomes the servant of the victim's family. This way of compensation is applied if the crime is unintentional.

Finally, the ritual ceremony provided by either Nyieya/Kwaaro, according to the village which the resolution process take place. It helps them to control serious conflicts by mollifying vengeful feeling among feuding families. They use the ceremony not only to create feelings of tolerance among feuding families, but also to avoid curses by ancestral souls. At the end of conflict resolution, the offender family pays all the compensation simultaneously for the victim's family and provides cows or bulls. From the cows or bulls they select one for ritual ceremony to purify the conflict sense. Both offender's and victim's family stand about for promise in front of the elder's council. After their promising they prepared spear to stick a cow or a bull, one after another. Then they fold up the tip of spears as a symbol of peace guarantee. Then, they slaughter a cow or a bull and split its body into two parts to sharing equally by starting from its forehead to tail. Therefore, the resolution process usually concluded with the ceremonial sacrifice of a cow or a bull and they assure that how much their resolution process is effective.

\section{Conclusion}

The Anyuaa community is one of African traditional communities who are living in Ethiopia and South Sudan. They have been established traditional institutions to realize indigenous knowledge for their social interaction. Their indigenous knowledge encompasses the skills, experiences and insights of people, applied to maintain or improve their livelihood, and handle conflicts. The main actors of their institutions are traditional king, Nyieya; headman, Kwaaro and elder's and family councils. They implement indigenous knowledge to resolve conflicts which occur 
within a community like inter-village, inter-group, inter-family, intra-family and other traditional game conflicts like agem and agaanya dance. The main responsibilities to mediate and arbitrate the conflict parties are lay on Nyieya, Kowaaro and family council. Under the process of conflict resolution, their indigenous knowledge practice with the aim of discovering the whole truth about the wrongdoing by giving freedom to explain and narrate every detail of the conflict and to vent their feelings without limiting them only to relevant issues. In addition to the families of the parties and the elders who are chosen to manage and lead the customary dispute resolution mechanisms, and other community members are allowed to attend and take part in the process.

Similarly, their reconciliation process finalize with compensation and purification to create more reintegration of the offender into his/her community. This is aim at restoring the relationship between the parties, and reintegrating the offender back into the society. To do this in their traditional conflict resolution process encourages the conflict parties to use words of forgiveness or rituals and facilitate reintegration into the communities. Therefore, in traditional African societies, indigenous knowledge play major role to conflict resolution besides to development process.

\section{References}

Ajayi, A. T., \& Buhari, L. O. (2014). Methods of conflict resolution in African traditional society. An International Multidisciplinary Journal, Ethiopia, 8(2), 138-157. http://dx.doi.org/10.4314/afrrev.v8i2.9

Akabogu, E. (2002). "Indigenous knowledge systems, integrity of the commons and emerging regimes of intellectual property rights in a Globalizing World." Presented at "The Commons in an Age of Globalization," the Ninth Conference of the International Association for the Study of Common Property, Victoria Falls, Zimbabwe, June 17-21, 2002. Retrieved June 2015 from http://www.hdl.handle.net/10535/1859

Babbitt, E.F. (2006). Mediating rights-based conflicts: Making self-determination negotiable. International Negotiation, 11(1), 185-208.

. (2009b). Conflict resolution and human rights: The state of the art. In: Bercovitch, J., Kremenyuk, V., \& Zartman, I.W. (eds.), Handbook of conflict resolution. Thousand Oaks, CA: Sage Publishers.

(2000). Bases of Traditional Conflict Management among the Buems of the Ghana-Togo Border. In: Zartman, I.W. (ed.), Traditional cures for more conflicts: African conflict "medicine." Boulder: Lynne Reinner Publishers.

Bar-Siman-Tov, Y. (2004). From conflict resolution to reconciliation, (ed.). Oxford University Press.

Bennett, T.W. (1993). Human right and the African cultural tradition transformation. p. 30-40. Retrieved from http://archive.lib.msu.edu/DMC/African\%20Journals/pdfs/transformation/tran022/tran022004.pdf

Bob-Manuel, I. (2000). "A cultural approach to conflict transformation: An African traditional experience." Term Paper. Written for the course: "Culture of Peace and Education" taught at the European Peace University Stadtschlaining Austria. Fall Semester 2000.

Boven, K., \& Morohashi, J. (2002). Best practices using Indigenous Knowledge. Nuffic, The Hague, The Netherlands, and UNESCO/MOST, Paris, France.

Brush, S. (1993). Indigenous knowledge of biological resources and intellectual property rights: The role of anthropology. American Anthropologist, 95(3), 653-686.

Department of Justice and Constitutional Development (2008). Republic of South Africa. Policy framework on the traditional justice system under the constitution. Pretoria, RSA, DOJ \& CD.

DeWalt, B.R. (1994). Using indigenous knowledge to improve agriculture and natural resource management. Human Organization, 53(2), 123-131.

Džuverovićl, N. (2011). New battles in Africa: Oil revenue management as a source of intrastate conflicts. The review of international affairs, $\operatorname{LXII(1141),51-60.}$

Fiseha, A. et al. (2011). The state of knowledge on customary dispute resolution in Ethiopia. In: Yntiso, Gebre, Fekade Azeze and Assefa Fiseha (eds.), pp. 21-36.

Fred-Mensah, B. (2005). "Nugormesese: An indigenous basis of social capital in a West African Community." IK Notes, No. 86, November. World Bank. Retrieved from www.worldbank.org/afr/ik/default.htm

Hampson, F.O. (2006). The risks of peace: Implications for international mediation. Negotiation Journal, 22(1), 13-30. 
Kestner, B. P., \& Ray, L. (2002). The conflict resolution training program. San Francisco: Jossey-Bass.

Kwaku, O., \& Morena, J. R. (2010). Indigenous conflict resolution in Africa: The case of Ghana and Botswana. University of Botswana.

Macfarlane, J. (2007). Working towards restorative justice in Ethiopia: Integrating traditional conflict resolution systems with the formal legal system. Cardozo Journal of Conflict Resolution, 8(487), 487-509.

Masina, N. (2000). Xhosa practices of Ubuntu for South Africa. In: Zartman, I.W. (ed.), Traditional cures for more conflicts: African conflict "medicine." Boulder: Lynne Reinner Publishers.

Michael, L. (2006). Conflict resolution and academic library instruction. LOEX Quarterly, 33(1/2), 6-9, 11.

Mutisi, M. (2009). Gacaca courts in Rwanda: An endogenous approach to post-conflict justice and reconciliation. Africa Peace and Conflict Journal, 2(1), 17-26.

Ngcongco, L.D. (1989). Tswana political tradition: How democratic? In: Holm, J. \& Molutsi, P. (eds.), Democracy in Botswana, Gaborone, Botswana Society. pp. 42-47.

Nwosile O.B. (2005). Traditional models of bargaining and conflict resolution in Africa: Perspective on peace and conflict in Africa. Ibadan: John Archers Ltd.

Okrah, K. A. (2003). Toward global conflict resolution. Lessons from the Akan traditional judicial system. Journal of Social Studies Research. Retrieved from www.findarticles.com/p/articles/mi_qa3823/is_200310/ai_nq304242

Olaoba, O.B. (2001). An introduction to Africa legal culture. Ibadan: Hope Publications, pp.1-2. Retrieved from http://catalog.hathitrust.org/Record/004305602

Osaghae, E. E. (2000). Applying traditional methods to modern conflicts: Possibilities and limits. In: Zartman, I.W. (ed.), Traditional cures for more conflicts: African conflict “medicine." Boulder: Lynne Reinner Publishers.

Regassa, T. et al. (2008). Restorative justice in Oromia baseline study. Addis Ababa, Central Printing Press.

Schellenberg, J. (1996). Conflict resolution: Theory, research and practice. Albany: State University of New York Press.

Tasew Tafese. (2010). Causes of conflict and traditional ways of conflict resolution among Anyuaa society in Gambella. AM Priniting and Packaging P.L.C. Addis Ababa, Ethiopia.

Warren, D. M. (1991). "Using indigenous knowledge in agricultural development." World Bank Discussion Paper No.127. Washington, D.C.: The World Bank.

Wasonga, J. (2009). Rediscovering Mato Oput: The Acholi justice system and the conflict in Northern Uganda. Africa Peace and Conflict Journal, 2(1), 17-26.

World Bank (1998). Indigenous knowledge for development: A framework for action. Washington, D.C.: The World Bank. 